\title{
Financial Literacy Education: Implication on the Economic and Social Life of the Teacher in Ghana
}

\author{
Juabin Matey ${ }^{*}$, Joseph Yennukua Duut ${ }^{2}$ and Mensah Felix Kombian ${ }^{3}$ \\ ${ }^{1}$ Development Institute for Vocational and Secretarial Studies, Bolgatanga, Ghana. ${ }^{2}$ Municipal GNAT Secretariat, \\ Box 441, Bolgatanga, Upper East Region, Ghana, ${ }^{3}$ Box 379, E/R Tamale, Northern Region, Ghana.
}

\begin{abstract}
Financial literacy education is a lifelong asset that every individual needs to function and fit well in modern-day society. It provides the financially savvy better decision making, best investment alternatives and family wellbeing. Unfortunately, most consumers especially in this part of our world appear relatively less active and less confident in participating meaningfully in the financial sector due to lack of knowledge about the complex nature of financial products and services and indeed the risk that goes with them. As a contribution in addressing this problem, this study looked at financial literacy education and its implication on the economic and social life of the teacher in the Upper East Region of Ghana. With a descriptive survey design, 118 participants responded to questionnaires. Results showed low levels of financial literacy among participants which can negatively affect their daily financial management. It is therefore definite that the financially literate has the advantage to undertake prudent alternative investment decisions and able to make informed retirement planning. Being financially illiterate adversely affects one's life in relation to the culture of savings, expenditure pattern, investment decisions and budgeting skills, making the individual economically insecure. The study has policy frontier implications; policy makers in the financial sector, governments, non-governmental organisations and equity owners are encouraged to come to the aid of consumers, especially teachers, by way of introducing professional teacher development programmes specifically tailored at uplifting their financial literacy knowledge and skills.
\end{abstract}

Key words: Financial, literacy, education, decisions, knowledge, teacher. JEL Classification: D11, D12, D14, D15, D91, G53.

\section{INTRODUCTION}

Financial literacy education (FLE) is a societal asset that cannot be ignored, and therefore needs a coordinated effort of all stakeholders in the financial sector to prioritise their goals in proclaiming the message in our societies (1). Knowledge of Financial Literacy (FL) enhances decision making skills of the individual, thereby allowing for better and informed decisions integral to an accomplished life. Financial Literacy is the ability to understand and effectively apply learnt financial skills, including avoidance of debt, careful prioritisation of needs and indeed living within family or individual means. Atkinson and Messy (2) define financial literacy as a blend of awareness, knowledge, skills, attitude and behaviours

*Address of Correspondence: Juabin Matey, Student, College of Distance Education, University of Cape Coast, Ghana. E-mail- e.juabin@gmail.com; Juabin Matey (0000-0002-6912-7048) - ORCID

(Received 14 December 2020; Revised 26 December 2020; Accepted 20 January 2021) 
important to the individual's financial wellbeing (3). Around the globe, governments have identified FLE as an intuitive remedy for citizens to master personal financial affairs that allows them the ability to mitigate potential negative effects (4-5). Due to lack of financial literacy education, we find a complete absence of planning acumen in most persons especially among public sector employees who ought to know better before retirement. Low savings, identity theft, extempore budgeting, credit-debt cycle trap, etc., are all attributes of poor knowledge of FL.

In some bold instances, policy makers in certain financially literate countries (eg Australia, Canada, Denmark, Finland, Germany, and Israel) have embraced financial literacy as a means of avoiding unhealthy financial decisions by launching a number of educational programmes to increase individuals' financial literacy and capability (6). Anecdotal reports however indicate that the majority of people in developing economies are not accessible to these financial literacy programmes (financial inclusion) which could help reduce the dizzying rates of poverty across financial illiterate nations through instilment of financial numeracy (7). This notwithstanding, more proactive countries have taken upon themselves to develop and implement FLE programmes ranging from ordinary FL campaigns to more structured seminars and workshops (8).

The issue of uninformed budget decisions and mismatch between income and expenditure amongst public sector employees is alarming in some of these financially illiterate nations. In fact, it is reported that, management of many companies in the U.S. have adopted financial education at workplaces as a tool to address personal financial management challenges (9). There are documented facts from behavioural finance, economics and psychology to the effect that well-designed FLE programmes can bring about enormous benefits to the consumer (7). Refera, Dhaliwal and Kaur (7) claim that FLE programmes do not only bring about theoretical knowledge but also induces improvement in self-control, avoidance of impulse buying, improved budgeting capabilities and improvement in culture of savings. It is however evidenced that, although Ghana was among the first few African countries to start the implementation of a National Strategy for Financial Literacy Education and Consumer Protection, about 80 percent of Ghanaians is still financially illiterate (10). A survey conducted by the Ministry of Finance and Economic Planning revealed that this proportion of the population is not financial inclusive (10). In furtherance, the survey indicated that even in instances where education on financial inclusiveness is given consumers, such knowledge is never translated into a positive behavioural change. Kunateh (2009) (11) (cited in Yankey, 2016) (12) segmented the illiteracy trend across regions in Ghana. Kunateh (11) states that whilst about 38 percent of public sector employees in the Northern sector of Ghana is financially functional illiterates, 44 and 51 percentage points are not financially savvy among the employees of the public sector in the Middle and Southern belts of Ghana respectively.

If all these efforts do not come to fruition, it is impossible for any economy to function well in today's technological world. This is so because, without financially skillful persons in strategic positions, the real economy suffers. As much as this applies to the global economy, any 
family or individual including the teacher will suffer backwardness without essential tools of financial literacy (13). This brings to bear the relevance of financial literacy in economic decision making. According to Lusardi and Mitchell (14) the early economic consideration in this area was by Bernheim (15-16). Bernheim (15-16) reiterated that most households in the US were financially illiterate, and that they adopted crude rules of thumb in their savings engagements. As pointed out earlier, the vulnerability of the individual to a new form of financial decision mistakes (scams of any form in varying proportions) will be eminent due to high financial illiteracy rate. Teachers' financial literacy status has been the target of this paper, since they are perceived as the most vulnerable group of persons by virtue of their position as role models in society and at learning centres. Teachers have a significant impact on the lives of school children, as pupils look up to them to live and aspire to be like them. There is therefore need for teachers to be professionally developed so that their productivity could be maximised through knowledge impartation (17). Teachers' professional development (TPD) could take the form of workshops or conferences on a broad spectrum of issues reflecting on a wide range of subject matters for the enhancement of their professional skills. There is no hard and fast approach in professionally developing the competence of the teacher; instead, TPD could be targeted to suit a particular content and context $(18,19)$. This lays bare TPD specific areas tailored at providing financial literacy education.

Totenhagen et al (20) posit that the relevance of providing the teacher with financial literacy education is long overdue and that teachers are not sufficiently knowledgeable on their own, let alone talk of imparting the knowledge to students. The demanding nature of the teacher's job with mosaic challenges urges them to find unconventional consolations for these problems. In finding solutions to these challenges, certain teacher category resort to unendorsed lifestyles such as excessive borrowing to ease family financial demand, catching up with hard liquor consumption to relieve stress and fatigue (21). It must be made clear however that, all these pressures are not the reserve of only the teacher; several other groups in the society suffer diverse pressures. A depressed live lived this way can, in certain instances lead to impulsiveness and can translate into isolated cases of suicidal ideation in worst scenarios (22). An estimated 80-90 percent of most suicide cases had a depression related condition (22). It is believed that with knowledge of financial literacy, the teacher will be guided to some extent. Most teachers have had broken marriages and failed family ties due to over indulgence in a number of social vices. These commonly emanate from unregulated lifestyles due to stress and depression and have affected their performance at school.

Notwithstanding the extant literature on financial literacy education, no such study has painstakingly been staged to link the impact of financial literacy education to the economic and social lifestyle of the teacher. We seek to fill this gap in literature.

\section{THEORETICAL AND EMPIRICAL LITERATURE}

There have been both theoretical and empirical works linked to financial literacy education. 
What appears a missing link however is the research on how consumers acquire knowledge of financial numeracy and how it's applied especially to their economic and social lives. The conventional microeconomic theory linked to savings and consumption decisions accepts that a rational and the well informed individual is most likely to spend less of his or her income in times of higher earnings than a functional financially illiterate individual (14). This is premised on the hypothesis that the rational financial literate will save during high earnings to support consumption in lean times. Ratifying the earlier works of (23) on financial numeracy and consumer psychological theory, (14) adopted the conventional microeconomic theory; the processing, understanding and acquisition of knowledge based on the consumer's capacity. Whilst in the case of the consumer psychological theory (which is said to address shortfalls under the financial numeracy theory), the ability of the consumer to comprehend and apply learnt skills was the missing link. Besides, Lusardi, Schneider and Tufano (24) found that high interest paid on loans is associated with less financially literate consumers. Moore (2003) equally established that majority of consumers are deficient in interest rate related numeracy when it comes to investment in securities.

Following these magna opera of (14) and (23), the FinLit Theory of the Rational Consumer becomes the offshoot seeking to explain the rationality of the consumer by not being impulsive his or her in daily purchases and not reckless in the application of available funds so as to maximise value for money. Reference is made of the very aged studies of Modigliani and Brumberg (25) and Friedman (26) cited in (14) on consumers' savings and the decumulation patterns to smoothen marginal utility. Macroeconomically, consumption is a combination of both autonomous and induced consumption and a function of income. This much talked of consumer Consumption function is of the form; $\mathrm{C}=\mathrm{a}+\mathrm{Yb}$, where $\mathrm{a}=$ autonomous consumption, $\mathrm{Y}=$ Income (Cash inflow) and $\mathrm{b}=$ induced consumption. In fact, the "a" plays the function of borrowing which occurs in the normal life of every consumer, whether there is money or not, and could result in piles of debt. The " $b$ " is the regulated income that is expended by the consumer on whatever items he feels expedient given an inflow of cash. Due to the concept of consumer rationality (14) under FinLit education, the " $b$ " could be channelled into savings or investments. A forthcoming paper looks at this FinLit Theory of the Rational Consumer in a more entailing form).

A number of verifiable studies have been cited to have examined why consumers acquire financial literacy skills and their correlation with personal savings and investment (27-28). In the case of Delavande et al (27), the basis of their argument in favour of acquiring financial literacy skills is that, people opt to invest especially, in higher return assets if they have better and informed financial literacy knowledge. In considering a two period model, Jappelli and Padula (28) established a strong relationship between wealth and financial literacy knowledge over a life cycle. They also found that, nationals of countries with generous Social Security benefits turn to have lower incentives for savings, hence reluctant to invest in financial literacy education.

The works of Lusardi and Mitchell (13) intervened to fill a literature gap created by (27) 
and (23) in empirical literature. They took into account features that are central to the savings theory, such as how borrowings are affected by the ability to save among others. Their works celebrate and simulate a multi-period dynamic life cycle model where they recognised that the individual's flair to invest is occasioned by a precursor investment in financial literacy. The relationship between financial literacy education and unregulated expenditure is expected to be negative. In the case of Disney and Gathergood (29) low knowledge of financial literacy was found to positively correlate with excessive expenditure. Implying that with little or no skills in FLE, the consumer is motivated to expand recklessly and to engage in opulence. On their part, Allgood and Walstad (30) linked fair knowledge of financial literacy to a regulated individual borrowing behaviour. Confirming this report, persons who experience high levels of indebtedness are found to have a poor knowledge of financial literacy (31).

The earlier work of Knapp (32) perceives knowledge of financial literacy as a way of empowering and improving quality of life of the society. What seem to be in support of this revelation are findings of Savla and Jorgensen et al (33) who conclude that, financial literacy education is beneficial to families as reflected in the enhanced relationship between families and by extension relative marital stability. Their study further reveals that increase physical and psychological wellbeing and improved financial decisions of the individual serve as a check on uncontrolled expenditure leading to better and quality lives. Corroborating these findings, Lusardi and Tufano (34) reported that the least financially savvy are most likely to incur high cost of transaction in their borrowing engagements thereby perpetuating themselves in the debt-cycle trap.

Uncontrolled expenditure by individuals due to high incidence of financial illiteracy was yet another finding by (21) when they carried a study on the impact of alcoholism on the teacher. Similarly, Kalichman, Simbayi, Kaufman, Cain and Jooste (35) established a negative relationship between unregulated expenditures and proper decision making. Kim and Garman (36) established a positive relationship between knowledge in financial literacy and financial management and individual wellbeing. Validating this claim, Cude (37) concludes that financial literacy education leads to less financial concerns, hence less stress and by extension less pressure. Consolidating these findings, Bahovec, Barbic and Palic (38) report that knowledge of financial literacy to be central in controlling and regulating the expenditure pattern of the individual. Considering the relevance of financial decisions on family stability and implication for regulation, Agarwal, Driscoll, Gabaix and Laibson (39) showed that high levels of financial illiteracy are usually associated with high levels of indebtedness. Implying that with knowledge of financial literacy, one can regulate expenditure and usually mindful of impulse purchases, which has a positive effect on debt thereby stabilising the family.

\section{MATERIALS AND METHODS}

Data were obtained using a cross sectional descriptive survey (see 21). Saunders, Lewis and Thornhill (40) consider survey design as being cost effective and ensures fair generalisability of conclusion if sampling is effectively done. They emphasise that a survey strategy allows for 
collected data to be quantitatively analysed using descriptive and inferential statistics.

\subsection{Study Population}

The study population is referred to as a set of cases from which a sample size is selected (40). Target population was all teachers in the Upper East Region of Ghana. The region was subdivided into blocs of three. They are the NorthEastern, Central and Western parts. This categorisation was researchers' own demarcation for purposes of data collection.

\subsection{Sample Size and Sampling Approach}

Using Krejcie and Morgan's (41) sample selection approach, out of 170 target population, a sample of 118 was chosen. The 170 target population made up of selected areas in Bongo and its environs, Navrongo and surrounding areas making up the North-Eastern part whilst Bolgatanga, Tongo and their catchment areas also constituted the Central bloc. Then we had Zebilla, Pusiga and environs from the Western bloc. It must be made clear here that data were collected under anonymity of participants. After stratifying the sample, simple random sampling technique was used to pick participants. We basically assessed financial literacy knowledge and its implication on the economic and social life of the teacher in the Upper East Region of Ghana.

\subsection{Data Type}

The study used both primary and secondary data. Primary data were in the form of questionnaires where 118 participants provided answers to questions raised in those questionnaires. Aside administration of questionnaires, Focused Group Discussions (FGD) was also used as an auxiliary data gathering technique in the three selected blocs of the Upper East Region of Ghana. Other sources of data were the hospitals and mental health units where data on lifestyle diseases were obtained. These sources formed the secondary data. Health bulletins, published works on FinLit and substance consumption related ailments equally formed part of the secondary data.

\subsection{Study Variables}

\subsubsection{Dependent variables}

A dependent or an outcome variable refers to a measurable characteristic that is subject to variations with a change in the regressor variables. Lifestyle of the teacher was used as a dependent variable with performance at school, alcohol / substance abuse, unregulated expenditure and nature of family relationship, as sub-categories. To effectively analyse data, the dependent variable (Lifestyle) assumed categorical values $($ Yes $=0$, No $=1$. Each subset was assumed as being good (when rated a score of 4 or 5) and not good (when rated a score of 3 , 2 or 1 ). Responses that fell within 1, 2, \& 3 were lumped as "No"=1, while scores of 4 and 5 also grouped as "Yes" $=0$. The object of this categorisation was to obtain results for a "No" or a "Yes" response to simplify data coding. (Survey scale: $<1.99=$ Strongly Disagree, $2.00-2.99=$ Disagree, $3.00=$ Neutral, $3.1-3.99=$ Agree and $4.00-4.99=$ Strongly Agree) .

\subsubsection{Independent Variable}

Following the works of Hung, Parker and Yoong (42), with a bit of modification, we measured Financial Literacy Knowledge (independent 
Variable) by way of simple performance-based approach (31). Basic budgeting skills, understanding interest rates, prioritising savings, credit-debt cycle traps, identity theft issues and safety were proxies for financial literacy knowledge (financial inclusion). A fivepoint Likert scale type questions were developed using anchors ranging from "strongly disagree" (1) to "strongly agree" (5). For instance, an item such as "you do mandatory monthly savings towards retirement". These subsets of financial inclusion allow consumers the ability to plan ahead, regulate expenditure to moderation and become more informed about economic activities (43).

\subsection{Model Specification}

$$
\begin{aligned}
Y= & B_{0}+B_{1}(B B S)+B_{2}(K I R) \\
& +B_{3}(S S)+B_{4}(I D T)+\varepsilon
\end{aligned}
$$

Where:

$\mathrm{Y}=$ is the Lifestyle of the teacher

BBS $=$ Basic Budgeting Skills

KIR = Knowledge in Investment Interest Rates

$$
\begin{aligned}
& \text { SS = Savings Skills } \\
& \text { IDT = Identity Theft } \\
& \mathrm{B}_{0}=\text { Constant, } \\
& \varepsilon=\text { Error term } \\
& \mathrm{B}_{1} \text { to } \mathrm{B}_{4}=\text { Coefficients of respective }
\end{aligned}
$$
regressor variables in the study

\section{RESULTS AND DISCUSSION}

Data collected from the field were analysed using Microsoft Excel and STATA 16.1. One of the fundamentals of this study was to find out why teachers in the larger population decide to resort to taking hard liquor as a means of subduing stress situations. Table 1 gives summarised responses obtained.

Table 1: Reasons for indulging in hard liquor consumption

For Pleasure at leisure

Management of stress

Aids proper reasoning

Courage to stand public delivery (eg speech)

Opulence of riches

Cure for ailments

Socialisation

Peer influence

Induces sleep

Spiritual attack

Booster to fight

Addiction

To escape immediate responsibility

Out of frustration (eg to forget worries)

Pacification of rites (eg funerals etc.)

Source: (see Rukundo \& Magambo, 2013) 
Table 2: Financial Literacy Education and the Teacher

\begin{tabular}{|c|c|c|c|c|c|c|}
\hline Statement & $\mathrm{SD}$ & $\mathrm{D}$ & $\mathrm{N}$ & $\mathrm{A}$ & SA & Mean \\
\hline $\begin{array}{l}\text { You are equipped with knowledge in } \\
\text { savings }\end{array}$ & 46 & 23 & 30 & 14 & 5 & 2.23 \\
\hline $\begin{array}{l}\text { Your knowledge in investment } \\
\text { instruments is fairly good }\end{array}$ & 23 & 33 & 32 & 21 & 9 & 1.81 \\
\hline $\begin{array}{l}\text { You are motivated to save } \\
\text { towards retirement }\end{array}$ & 19 & 41 & 30 & 16 & 12 & 1.84 \\
\hline $\begin{array}{l}\text { You normally budget on what to spend } \\
\text { your money before the month ends. }\end{array}$ & 22 & 39 & 44 & 9 & 4 & 1.81 \\
\hline AVERAGE MEAN & & & & & & 1.92 \\
\hline
\end{tabular}

Reasons provided in Table 1 were adopted from (21). We found about 97 percent of reasons for drunkenness in Uganda being reiterative in our study areas. There could be other latent reasons, but due to limitedness of the sample, these common reasons were identified.

Respondents were asked to rate statements on the independent variable (financial literacy knowledge). In fact, an average mean of 1.92 was recorded translating into a strong disagreement, an indication of poor financial education amongst the teacher population across the study areas. On the issue of whether respondents had knowledge in savings, a mean of 2.23 was scored reflecting a disagreement as can be inferred from interpretation of the survey scale. This revelation resonates with results produced by (15-16) when he reiterated that majority of US families are financially illiterate with crude methods of savings. In a further probe, respondents confessed that, most of them (teachers) don't live beyond a week with their salaries and do not know how these monies are expended due to lack of planning ahead of salary payment.

In another development, a 1.81 mean was recorded when participants were quizzed if they had a fair knowledge in investment tools. This 1.81 score logically falls under strong disagreements. This implies, with poor knowledge in investment, participants are exposed to making improper financial decisions. Delavande et al (27) succinctly state that, people will opt to invest if they have better and informed financial literacy knowledge. What researchers could decipher from these trends of responses was poor financial literacy education across the study sample. Coincidentally, the practice of budgeting was functionally absent as shown by a similar 1.81 mark recorded. As for the idea of being motivated to save, it was an eyesore, as respondents had a poor culture of savings indicated by a mean of 1.84 . Expectedly 
enough, some of the participants told researchers majority of them is frustrated with multiple loans from different lenders. It was revealed in a follow up question that teachers contract new loans to offset old loans and so are usually left with a token to manage till the month ends.

\subsection{Life Style Variables of the Teacher}

The dependent variable (LifeStyle) was further categorised into four subsets with each subset assuming a range of anchors; "Yes" (rated by a score of $4 \& 5$ ) and "No" (rated by a score range of $3,2 \& 1$ ). What it seeks to explain is, all scores by participants on a particular item of question that were either 1-3 assumed a categorical value of $1=$ "No", and scores which were 4 and 5 were assigned $0=" Y e s "$. This was to facilitate data coding and analysis.

Table 3: Response Level on the Lifestyle of the Teacher (Outcome Variable)

\begin{tabular}{|c|c|c|c|c|c|c|}
\hline Statement & SD & $\mathrm{D}$ & $\mathrm{N}$ & A & $\mathrm{SA}$ & Mean \\
\hline $\begin{array}{l}\text { Teachers into excessive liquor consumption } \\
\text { perform better at school }\end{array}$ & 66 & 34 & 10 & 8 & 2 & 1.63 \\
\hline $\begin{array}{l}\text { Most teachers do not indulge } \\
\text { in liquor abuse }\end{array}$ & 3 & 5 & 8 & 67 & 35 & 1.93 \\
\hline $\begin{array}{l}\text { Teachers into liquor abuse do not relate well } \\
\text { with family members and have marital instability }\end{array}$ & 77 & 30 & 5 & 4 & 2 & 1.51 \\
\hline $\begin{array}{l}\text { Teachers who overly indulge in hard liquor are } \\
\text { more likely to have uncontrolled expenditure. } \\
\text { and are highly indebted }\end{array}$ & 22 & 39 & 44 & 9 & 4 & 1.81 \\
\hline AVERAGE MEAN & & & & & & 2.11 \\
\hline
\end{tabular}

Source: Field Survey (2020)

Table 4: Regression Model Summary

\begin{tabular}{ll}
\hline & Regression Statistics \\
\hline Multiple Regression & 0.871561 \\
R-Square & 0.759618 \\
Adjusted R-Square & 0.672207 \\
Std Error & 2.269789 \\
Observation & 118 \\
\hline
\end{tabular}

Source: Researchers' own computers from field data (2020) 
The relationship between the study variables was established by using the correlation coefficient. A strong positive relationship exists between paired studied variables, reflective in the approximate R-value (0.872) [Table4]. The R-Square value (0.76) or about 76 percent explains the variance in the power of the independent variable (Financial literacy education) to influence the outcome variable
(Lifestyle of the teacher), as in performance in school, consumption of alcohol and other substances, unregulated expenditure and nature of relationship with family members. What it tells the readership is that, 24 percent of the teacher's lifestyle is influenced by other latent factors not captured in this study model. This makes the model a good fit.

Table 5: Analysis of Variance (ANOVA)

\begin{tabular}{llllll}
\hline & Sum of & & Mean & \\
& Square & Df & Square & F & Sig \\
\hline Regression & 179.08 & 17 & 44.77 & 8.69 & 0.000 \\
Residual & 56.67 & 100 & 5.15 & & \\
Total & 23.75 & 117 & & & \\
\hline
\end{tabular}

Source: Researchers' own computers from field data (2020)

It is evidenced from Table 5 that with significance value of 0.000 , the data could be relied upon to make a conclusion. The F-value is greater than the critical values at both $1 \%$ and $5 \%(2.575<8.69 \& 1.96<8.69)$. That is, even if the regression were run based on $1 \%$ or $5 \%$ margin of error respectively, teachers' performance at school, alcohol and substance consumption, relationship with families and unregulated expenditure would still be significantly influenced by knowledge in financial literacy.

Table 6: Financial Literacy and Teachers' Lifestyle

\begin{tabular}{lrrc}
\hline & Coefficient & t-value & $p$-value \\
\hline BBS & 0.267 & -1.49 & 0.074 \\
KIR & 0.234 & -4.88 & 0.001 \\
SS & -0.217 & -0.98 & 0.050 \\
IDT & -0.670 & 2.48 & 0.030 \\
Constant & 18.480 & 5.13 & 0.003 \\
\hline
\end{tabular}

Source: Researchers' own computers from field data (2020)

A basic budgeting skill (BBS) is one of the sub-regressor variables that were considered under FLE. Table 4 reports a significant positive relationship between teachers' lifestyle and financial literacy. A study by Bahovec et al (38) identified that financial literacy education is central in putting a check on extravagancy and has a resonation with our findings. Thus, the more knowledgeable the teacher in budgeting rudiments the more careful he is with his or her spending. It enables the consumer prepare family budget with skills to take care of pressing family needs. This is in line with Huhmann and McQuitty's (23) consumer psychological theory. 
Linked to these same findings, Agarwal et al (2008) showed that high levels of financial illiteracy are usually associated with high levels of reckless spending and indebtedness. This implies with knowledge in financial numeracy such as basic skills in budgeting, one has the urge to regulate opulence which avoids debt overruns. There is a linked to the FinLit theory of the rational consumer. With high values of the small "a" in the consumption function, the individual is much exposed to more debt relatively, reiterating the harm done to consumers. Besides, if the willingness to spend more as a result of cash-in-flow (small " $b$ ") is unreasonably high, it could be as a result of high financial illiteracy rate and similarly puts the consumer in a financially unstable situation.

Knowledge in investment rates helps the consumer (teacher) make informed decisions regarding best investment alternative opportunities, thereby being able to diversify risk of loss. Table 6 reports a statistically positive relationship between KIR and lifestyle of the teacher. Given that the teacher is financially savvy, he stands to benefit in many ways; he is made aware of investment alternatives by spreading his investments into different classes of securities. Lusardi et al (24) found that high interest paid on loans is associated with consumers with low financial literacy knowledge. Lusardi and Mitchell (2014) recount how mortgage defaults during the global financial crisis played a role due to poor knowledge in debt management since majority of consumers did not know how much interest rates were charged on their credit cards (14).

Identity theft occurs when an individual consumer loses hold of confidential information to his or her credit card (this is likened to an individual's Mobile Money [MoMo] Wallet PIN). Unaware of the nitty-gritties of credit cards and how compromised confidential information could affect them, most consumers (teachers) are exposed to identity theft. Table 6 reports a statistically negative relationship between knowledge in financial numeracy and the teacher's economic life. With a working knowledge of FL, consumers and by protraction teachers become less vulnerable. The implication is that, with a unit effort to educate the teacher on the relevance of financial literacy skills regarding being careful not to give out his or her MoMo PIN, consumers' (teachers') exposure to identity theft reduces (-) by 67 percent. Therefore a unit effort made by relevant policy makers and equity owners in availing financial literacy education to teachers in the areas of basic budgeting skills, insights into prioritising savings, credit-debt cycle traps and identity theft issues, the negative effects on the consumer (teacher) will be less severe than the positive effects.

Generally, most of the teachers interviewed confessed that they never kept any money in their bank accounts and added that a section of them is traumatised with unfulfilled claims to creditors (drinking bar operators and provision shop owners). These findings appear to be in sink with Rukundo and Magambo's (21) study when they explained how stressful and myopic some teachers become due to trauma thereby pushing some into finding consolation in hard substance consumption.

\section{LIMITATION OF THE STUDY}

The researchers faced problems of precise and standard measurement method, as the simple approach was finally relied upon (see 24). The 
limited nature of the sample was quite a deficient. This was brought about by the inability of researchers to have travelled far deep into the hinterlands and across selected study areas to have fair idea of participants' financial literacy knowledge. The initial intention of researchers was to cover all public sector workers so the problem of financial literacy education could be well measured and appreciated. This notwithstanding, researchers made sure care was taken not to compromise the outcome to allow for generalisability of results.

\section{FURTHER RESEARCH}

A further study involving all public sector employees with a much larger sample across the country and a well entailing financial literacy measure to test financial literacy and its effect on financial stability of consumers is recommended.

\section{CONCLUSIONS AND RECOMMENDATIONS}

The Individual's (teacher's) ability to manage personal finance is largely dependent on financial education which enhances his financial literacy. Financial literacy education improves one's successful involvement in any economic activity by way of positive savings habits, healthy investment decisions and debt management. Even in situations where some participants reportedly had fair knowledge, its applicability was problematic. Knowledge of financial literacy provides a fertile ground to reduce indebtedness and enhances the individual's financial conditions thereby reducing financial instability related challenges such as stress and depressions. Until financial literacy education is instilled in teachers, their savings, investment and budgeting culture will be nothing to celebrate over. Participants barely have any money on them or in their bank accounts for emergency and contingency due to personal deficit budgeting issues resulting from less exposure to financial education. Financial literacy education needs a consistent and frequent appeal to the minds of individuals. Less than 1 percent of what is thought and delivered on financial literacy education is being practically utilised by beneficiaries.

Again, participants have unsatisfactory performance at school due to financial instability related challenges from unresolved financial problems which ultimately has an adverse effect on students' performance. Besides, participants' relationship with family is greatly affected. In isolated scenarios, it was inferred that relationships of some participants lacked stability and therefore threatened with divorce. There were cases of job losses or severe reprimand by teacher authorities for unsatisfactory behaviour emanating from absenteeism due to excesses in the lives of these teachers. The study has policy frontier implications; policy-makers, governments, nongovernmental organisations and equity owners should come to the aid of teachers by way of improving on professional teacher development programmes specifically tailored at uplifting their financial literacy knowledge and skills. It is indeed economically unhealthy to live devoid of financial literacy education.

\section{CONFLICT OF INTEREST}

There is no conflict of interest in this present research paper. This research work is not a part of any other studies and it is our original work. 


\section{REFERENCES}

1. National Financial Educators Council Updates and Launches All-new Financial Literacy Resources, (2019).

https://www.financialeducatorscouncil.org/newupgrades-and-expanded-resources/

2. Atkinson A, Messy F. "Measuring Financial Literacy: Results of the OECD / International Network on Financial Education (INFE) Pilot Study", 2012;14, OECD Working Papers on Finance, Insurance and Private Pensions, No. 15, OECD Publishing. DOI: $10.1787 / 5 \mathrm{k} 9$ csfs90fr4-en

3. Nkrumah OE. Assessing the level of financial literacy among teachers: A case study of Sekyere East District of Ashanti Region of Ghana. 2015.

4. Fernandes D, Lynch JG Jr, Netemeyer RG. Financial literacy, financial education and downstream financial behaviors, Management Science. 2014; 60: 1861-1883. DOI:10.1287/mnsc.2013.1849

5. Willis, L. The financial education fallacy; An Econ Rev. 2012; 101: 3, 429-434

6. Stolper OA, Walter A. Financial literacy, financial advice, and financial behaviour. Bus Econ, Springer, 2017; 87, 581-643; DOI 10.1007/s11573-017-0853-9

7. Refera MK, Dhaliwal NK, Kaur J. Financial literacy for developing countries in Africa: A review of concept, significance and research opportunities. Journal of African Studies and Development. 2015; $8: 1,1-12$

8. World Bank. Financial Education Programs and Strategies Approaches and Available Resources, 2014

9. Brown BB, Mounts N, Lamborn SD, Steinberg L. Parenting practices and peer group affiliation in adolescence. Child Development. 1993; 64, 467-482.

10. Ghana News Agency $80 \%$ of Ghanaians are financially illiterate. 2019.

11. Kunateh MA. Financial literacy low among adults in Northern Ghana survey. 2009.

12. Yankey MB. Financial literacy among public sector workers in the cape coast metropolis, University of Cape Coast, Ghana. 2016.

13. Lusardi A, Mitchell OS. Financial literacy around the world: an overview. Journal of Pension Economics and Finance. 2011c; 10:4, 497-508.

14. Lusardi A, Mitchell OS. The economic importance of financial literacy: Theory and Evidence. J Econ Lit. 2014; 52:1, 5-44. DOI:10.1257/jel.52.1.5

15. Bernheim D.Tax policy and economic growth. Washington, DC: American Council for Capital Formation. 1995; 1-30.
16. Bernheim D. Financial illiteracy, education, and retirement saving. In: Mitchell, O.S., Schieber S, editors. Living with Defined Contribution Pensions, Philadelphia: University of Pennsylvania Press; 1998; 38-68.

17. Wei RC, Darling-Hammond L, Andree A, Richardson N, Orphanos S. Professional learning in the learning profession: A status report on teacher development in the United States and abroad. Dallas, TX. National Staff Development Council. 2009.

18. Guskey TR. Closing the knowledge gap on effective professional development. Educational Horizons. 2009; 87:4, 224-233.

19. Compen B, De Witte K, Schelfhout W. The role of teacher professional development in financial literacy education: A systematic literature review. Educational Research Review. 2019; 26, 16-31.

20.Totenhagen CJ, Casper DM, Faber KM, Bosch LA, Wiggs CB, Borden-Youth LM. Financial literacy: A review of key considerations and promising delivery methods. Journal of Family and Economic Issues. 2015; 36: 2, 167-191

21. Rukundo A, Magambo J. Professional impotence: Impact of alcoholism on secondary school teachers in Uganda. International Journal of Alcohol and Drug Research. 2013; 71-74, DOI: 10.7895/ijadr.v2i2.104

22. Shin Y-C, Lee D, Seol J, Lim S-W. What kind of stress is associated with depression, anxiety and suicidal ideation in Korean employees?. Journal of Korean Medical Science. 2017; 32:5, 843-9. 10.3346/jkms.2017.32.5.843

23. Huhmann BA, McQuitty S. A model of consumer financial numeracy. International Journal of Bank, Marketing. 2009; 2:4, 270-293. Emerald Group Publishing Limited, DOI 10.1108/02652320910968359

24. Lusardi A, Schneider DJ, Tufano P. Financially fragile households: Evidence and implications. Brookings Papers on Economic activity, 2011; 83134.

25. Modigliani F, Brumberg R. Utility analysis and the consumption function: An Interpretation of Crosssection Data. In: Kurihara, K., editor. Post-Keynesian Economics, 1954; 388-436.

26. Friedman M. A theory of the consumption function. Princeton: Princeton University Press, 1957.

27. Delavande A, Rohwedder S, Willis R. Preparation for retirement, financial knowledge and cognitive resources. MRRC Working Paper Series. 190, 2008.

28. Jappelli T, Padula M. (2013). Investment in financial literacy and saving decisions. Journal of Banking and Finance. 2013;37: 2779-2792. 
29. Disney R, Gathergood J. "Financial literacy and indebtedness: New evidence for UK Consumers," Discussion papers 11/05. University of Nottingham, Centre for Finance, Credit and Macroeconomics (CFCM), 2011.

30. Allgood S, Walstad W. "The effects of perceived and Actual financial knowledge on credit card behavior," Networks Financial Institute Working Paper, 2011; 15.

31. Gathergood J. "Self-Control, financial literacy and consumer over-indebtedness". Journal of Economic Psychology. 2012;33: 590-602.

32. Knapp JP. The benefits of consumer education: A survey report. Yipsilanti, MI: Eastern Michigan University, Consumer Education Center. 1991.

33. Jorgensen BL, Rappleyea DL, Taylor AC. Understanding financial literacy and competence: considerations for training, collaboration and referral for MFTs, 2014; 5:1, 2. DOI: 10.4148/1944-9771.1062

34. Lusardi A, Tufano P. Debt literacy, financial experiences, and over indebtedness, Working Paper $14808,2009 a$

35. Kalichman SC, Simbayi LC, Kaufman M, Cain D, Jooste S. Alcohol use and sexual risks for HIV/AIDS in Sub-Saharan Africa: Systematic review of empirical findings. Prevention Science. 2007; 8: 141-151. Doi: $10.1007 / \mathrm{s} 11121-006-0061-2$
36. Kim J, Garman ET. (2003). Financial stress and absenteeism: An empirically derived research model. financial counseling and planning. 2003;14:1

37. Cude BJ (2010). Financial literacy. The Journal of Consumer Affairs. 2010; 44:2.

38. Bahovec V, Barbić D, Palić I. Testing the effects of financial literacy on debt behavior of financial consumers using multivariate analysis methods. Croatian Operational Research Review. 2015; 361371

39. Agarwal S, Dricsoll JC, Gabaix X, Laibson D. Learning in the credit market. National Bureau of Economic Research. Working paper No. 13822, 2008.

40. Saunders M, Lewis P. Thornhill A. Research methods for business students 6th ed. Harlow, Essex: Pearson Education Limited, 2012.

41. Krejcie RV, Morgan DW. Determining sample size for research Activities, Educational and Psychological Measurement. 1970.

42. Hung AA, Parker AM, Yoong JK. Defining and measuring financial literacy. RAND Working paper series no. 708, 2009

43. Coşkuner, S. Linking financial management practices to financial literacy: Evidence, from Turkey. International Journal of Scientific \& Engineering Research. 2017; 8:12, 1214-1221. 